\title{
Regards and Views toward International Accounting Standards Setting: A Critical Examination and Discussion
}

\author{
Afzal Ahmad* \\ Assistant Professor of Accounting, Department of Business Administration, International Islamic University Chittagong, Chittagong, \\ BANGLADESH \\ *E-mail for correspondence: afzaliiuc@gmail.com
}

\begin{abstract}
Accounting information is the basis for the stakeholders who take different economic decision time to time by assessing those accounting information reported by the business organization. That's why; international accounting standard setting committee aims to protect the interest of the stakeholders by formulating a high-quality reporting standard. But this standard setting process is hindered by many external lobbying groups like government, political, economic and corporate group because there are the agency and other problems. This study aims to examine and discuss the theoretical and conceptual frameworks like different approaches and theories like a free market and regulatory approach. Moreover, it is still a debate whether free market or regulatory approach ensures the interest of the stakeholders more. However, this study identifies that standard setting process should be a holistic approach that should protect the interest of not only the stakeholders but also the organization.
\end{abstract}

Keywords: IAS, Accounting Information, Stakeholders, Marketing System Quality, Standard Setting Process, Holistic Approach

\section{INTRODUCTION}

The International Accounting Standard aims to protect the interests of the investors and public by setting a set of high quality, enforceable and understandable accounting standard (Deegan and Unerman, 2008). But the standard setting of accounting is highly influenced by different external lobbying parties because they have some private and individual interest behind it (Georgiou, 2005). According to McLeay et al. (2000), the impact of lobbying on standard setting on accounting is multidimensional and multidirectional because the external party lobbies for favorable standard while the internal party lobby so that their proposed standard become intact for the betterment of the investors and public. In fact, it is still a debate whether free market approach or regulatory approach is beneficial for the standard setting on accounting (Hill et al. 2013). According to Porter (2005), there are some economic and political groups who have substantial influencing power over the standard setting on accounting and this influence is multidimensional because it has some positive and negative impacts on the stakeholder's economic decision-making process.

\section{ObJective ANd Methodology Of the Study}

The aim of the study is to examine critically the different methods on standard setting in accounting, many relevant theories like positive accounting theory, public interest theory, capture theory; economic interest group theory, political lobbying theory and agency theory have been used to discuss the current issue. Side by side, different approaches like free market approach and regulatory approach have been considered for the deeper aspect of the phenomenon. Besides, the recent publications, articles and books have been used to discuss the critical aspect of the issue.

\section{LITERATURE REVIEW}

Accounting is the language of the business organization and thus standard setting in accounting is very significant for all stakeholders as it helps to reveal the true picture of the organization. That's why; there are many external and internal influences or lobbying in case of setting the standard in accounting (Tricks and Hargreaves, 2004). According to Kirsch and Day (2001), it is challenge for the standard setters because many external factors influence their decision-making process. Agency and system theory were employed during 1993-98 as theoretical bases for studying the influence of lobbying on IASC. According to Deakin (1989), many external parties use the some formal and informal channels to make a direct lobbying to the IASC. On the other hand, IASC itself sometimes lobbies external parties so that they support for their proposed standard and activities. Georgiou (2004) in this regard concluded that lobbying on standard setting in accounting is multidirectional.

There are many theories of lobbying demanding that there are certain economic groups who contain a disproportionate amount of political pressure and 
resources that influence the regulatory decisions. According to Kelly (1982), corporate firms expecting reduced earning because of having compliance on accounting standard highly oppose to the changing accounting standard. Kim (2008) in support of Kelly (1982) concluded that firms that have higher leverage generally oppose the accounting standard that makes them bound to increase the volatility of income because of protective covenants in loan agreements. This reveals that there is a strong relationship between firm's objective and its propensity to lobby the accounting standard board.

Lobbying efforts are sometimes perceived as unidirectional because the stakeholders generally lobby the standard setting organization. Sutton (1984) in this point argued that there are a single government, single standard-setter and separate regulatory agency containing enforcement powers. According to freemarket approach, there must be some price for accounting information based on which they take their economic decision because it is less likely a commodity in trade. Procházka (2006) in this regard concluded that regulatory approach can be helpful in case of standard setting on accounting. But others concluded that it is still a debate whether it should be made considering the private or public sector. Supporters of free market approach concluded that regulatory approach is not necessary because the market can supply the required information in standard setting.

According to Kenny and Larson (1993), the business organizations are bound to supply the required information regarding their operation of business to the stakeholders and failure to this activity may increase the operation cost according to the agency theory. So, the regulatory approach can be a solution to market failures because it is mainly concern about the interest of the firms and the stakeholders. Zeff (2002) conclude that political lobbying is the most influential one in case of standard setting on accounting because they have easy access to the parliament and to the business community. According to Zeff (2002), there is chance to face the political lobbying if the new or proposed accounting standard aims to reduce the earning of the organization or make the earning more volatile over the period. Hill et al. (2013) in support of Zeff (2002) opine that companies lobby against any measures that increase the earning because earning is linked with a tax on income in many countries like Germany. It is the duty of the standard setters to identify and determine to what extent the political groups or lobbyists raise valid arguments and issues in the light of conceptual and theoretical framework.

Government can also be engaged in lobbying on the proposed accounting standards. According to Georgiou (2005), government can go for political and regulatory lobbying if there is a possibility that the proposed standard will lead the companies report volatile or lower earning because these might throw out plans for expansion and withholding of investment in capital goods. In consequence, this may increase the unemployment rate that the government of a country may wish to avoid.

So, it can be said that lobbying is a common phenomenon for many external parties like economic, political, corporate and government groups to keep their interest intact. But the regulatory or free market approach has been found as more concern about protecting the interest of the stakeholders who make the economic decision only analyzing the accounting information.

\section{Standards Setting Methods}

\section{Free market approach}

The free market approach considers the accounting information as economic goods. So, the price of these goods will be determined by the market forces like demand from the users of accounting information and supply from the interest preparers. According to Deegan and Unerman (2008), when these two market forces interact at the equilibrium point, the optimal information is attained. The organizations should provide the accounting information to the stakeholders for making their economic decision. According to Scott (2003), they demand the information at an average price above the cost of production. Gaffikin (2009) in this regard concluded that regulation is not necessary because the market itself is reliable to provide optimal information that is efficient. For instance; US stock exchange needed audited financial statement because of its self-interest not because of government regulation.

\section{Regulatory approach}

The regulatory approach to accounting means the process of imposing restrictions on the content and preparation of financial reports. According to Brasher and Lowery (2006), regulation is very important in a case of standard setting because it enhances the application and harmonization of the accounting standard. According to Gorton (1991), accounting information is viewed as the public goods while it is regarded as the economic goods in case of free market approach. But it is argued that there are many free riders in this approach because many people do not pay for the publicly offered information while others pay for it. Many researchers (Francis, 1987) in this regard argues that market has failed and inefficient because free riders use the publicly provided information for their own interest next to the other users who have paid for it. Thus, this approach is seen as the solution to the free market deficiencies by many opponents.

\section{Agency Theory}

This theory assumes the company as the web of contracts, and that's why the free market approach can be explained with the help of agency theory. According 
to Scott (2003), many stakeholders contribute the benefit of the companies and management aims to coordinate these contracts and groups. Thus, it can be argued that agency theory is nothing but the relationship between the agent and principal. This theory aims to decrease the agency costs with the help of market mechanisms. The proponents of free market argue that there might be conflict of interest between the principal and agent as the agent wants to maximize the utility.

\section{Positive accounting theory}

Many (Deegan and Unerman, 2008) argues that this theory is basically the extensions of agency theory because it considers the entity as the "nexus of contracts" between managers and owners. According to Aronsson and Sjostrom (2007), this theory assumes that individual act for their own benefit and they always search for opportunities to maximize their wealth. It concludes that private contracts can be used to reduce the agency cost using alignment of the interest of both managers and owners. Thus, the output of the accounting information determines the performance of the contract. Therefore, it is the duty of the management to provide the picture of the organization and management.

\section{Public interest theory}

This theory is supported by many critiques that are in favor of regulation because it is response to the public demand for correction of inefficient market. According to Giner and Arce (2007), this theory aims to provide information for the greater benefit of the society as a whole instead of vested interests. Singer (2007) in this regard opines that regulation helps to build confidence and trust to the society in terms of resources allocation and use to the productive and profitable way if this theory is applied. Opponents of this theory argue that regulation undermines the political and economic power and thus a foe to the public interest.

\section{Capture theory}

This theory is to some extent similar with the public interest theory because it aims to serve the interest of whole people instead of personal interest. But with the passage of time, this theory it tends to the capture theory by compromising its independence. It is evident in the case of large audit and accounting firms that have good control over setting process of the accounting standard. For example; eight accounting firms in the USA efficiently controlled the decisions of FASB to follow their own interest on behalf their clients. Chen et al. 2012) concluded that political, economic, institutional, social and legal forces are playing the important role to achieve the market equilibrium and standard setting for self-interest.

\section{Economic interest group theory}

This theory is commonly known as the private interest group theory because they can influence the regulator for the greater purpose of securing economic benefits. According to Zeff (2002), highly regulated and politically pressured organizations are accustomed to lobbying for setting accounting rules for their own benefit. The rationale of this theory is that regulation is important to protect the interest of the economic interest group because the lobby is done to ensure the private interest. That's why; some argues (Larson, 1997) that regulations serves the interest of the private groups who finds lobbying very difficult.

\section{Political lobbying theory}

This theory is one of the most influential among all theories in case of setting the standard in accounting. According to Zeff (2002), different parties in the society are intended to lobby the politicians to ensure their own interests instead of societal interest. For instance; there was a need for change in Germany Commercial Code and the decision makers in this case were the parliamentarians and industry and audit associations were the lobby groups. Thus professional associations played a strong role because they had easy access to the parliamentarians.

\section{Key Findings AND CONCLUSION}

Accounting information is the basis for the stakeholders who take different decision time to time by assessing those accounting information reported by the business organization. That's why; international accounting standard setting committee aims to protect the interest of the stakeholders by formulating a high-quality reporting standard. The study also finds some researchers argue for free market approach while others argue for the regulatory approach to the accounting standard. Actually, it is still a debate whether free market or regulatory approach ensures the interest of the stakeholders more. However, this study identifies that standard setting process should be a holistic approach that should protect the interest of not only the stakeholders but also the organization.

It is evident from the above critical discussion that lobbying has become a very common phenomenon in the standard setting of accounting because there are some powerful or influential economic and political group which influence substantially on this process in order to make it favorable for them. Political and economic lobbying has been found very strong because they have easy access to both parliament and business community. The free market approach considers the accounting information as an economic commodity and thus the equilibrium price is determined by the users and preparers of accounting information. It also argues that regulatory approach is not at all necessary in this case because the market itself is self-sufficient to provide required information to the interested parties. On the other hand, regulatory approach demands that it is very important because it ensures the interest of the mass 
people by imposing restrictions on the contents of financial reports, accounting standard setting and preparation of the contents. However, many researchers come to a conclusion that lobbying has come because there are an agent and principal relation between the owner and employee of the organization. The agent always wants to show the fabricated data for their own benefits while the owners want to get the true picture of the organizations which is also the objective of the stakeholders. The impacts of either corporate or political or economic lobbying on the standard setting on accounting are thus multidimensional and it is a challenge for the setters to keep their own proposed standards intact. Thus, it is still a debate whether free market or regulatory approach will be the best solution for the stakeholders in case of the economic decision by assessing the accounting information.

\section{REFERENCES}

Aronsson, P. and Sjostrom, A. (2007) Disclosure requirements related to investment property; Gothenburg: University of Gothenburg

Brasher, H. and Lowery, D. (2006) The corporate context of lobbying activity, Business and Politics, 1(8), pp. 3-21

Chen, H., Parsley, D. and Y. Yang, (2012) Corporate lobbying and Financial Performance; University of ColoradoBoulder Working Paper

Deakin, E.B. (1989) Rational economic behavior and lobbying on Accounting Issue: Evidence from the oil and gas industry; The accounting review, January, pp. 111-147

Deegan, C. and Unerman, J. (2008) Financial Accounting Theory: European Edition. McGraw-Hill

Francis, J. R. (1987) Lobbying against proposed Accounting Standards: The case of Employers; Pension Accounting; Journal of Accounting and Public Policy 6, pp. 23-48

Gaffikin, M. (2009) Regulation as Accounting Theory; Australia: University of Wollongong

Georgiou, G. (2004) Corporate lobbying on accounting standards methods, timing and perceived effectiveness, Abacus, 40(2), pp. 201-234

Georgiou, G. (2005) Investigating corporate management lobbying in the UK accounting standard setting process: A multiissue/multi-period approach, Abacus, 41(3), pp. 289-324

Giner, B. and Arce, M. (2007) Lobbying on accounting standards: an analysis of the due process of IFRS 2 on share-based payments; Working paper series, w55, University of Valencia.

Gorton, D.E. (1991) The SEC decision not to support SFAS 19: A case study of the effect of lobbying on standard setting; Accounting Horizons, March, pp. 11-39

Hill, M. D., Kelly, G. W., Lockhart, G.B., and Ness, R.A.V. (2013) Determinants and Effects of Corporate Lobbying; Financial Management; Winter, pp. 931-957

Kelly, L. (1982) Corporate Lobbying and Changes in Financing or operating Activities in reaction to FAS no. 8; Journal of Accounting and Public Policy 1(2), pp. 112-172

Kenny, S. Y. and Larson, R.K. (1993) Lobbying behavior and the development of International Accounting Standard: The case of the IASC's Joint Venture project; European Accounting Review; 2(3), pp. 511-548

Kim, H. (2008) Corporate Lobbying Revisited; Business and Politics 10, pp. 2-21

Kirsch, R. J. and Day, R. (2001) Lobbying and the International Accounting Standard Committee; Southern Connecticut State University Press; New Haven

Larson, R. K. (1997) Corporate lobbying of the International Accounting Standard Committee; Journal of International Financial management and Accounting 8:3, pp. 2-27

McLeay, S., Ordelheide, D., \& Young, S. (2000) Constituent lobbying and its impact on the development of financial reporting regulations: Evidence from Germany. Accounting Organizations and Society, 25 (1), pp. 21-76

Porter, T. (2005) Private authority, technical authority, and globalization of accounting standards, Business and Politics, 7(3), 3-23

Procházka, D. (2006) Approaches to the regulation of the Accounting; European Financial and Accounting Journal. 1(2), pp. 22-47

Scott, W.R. (2003) Financial Accounting Theory, $3^{\text {rd }}$ Edition, Prentice Hall, Toronto

Singer, D. (2007) Regulating Capital: Setting Standard for the International Financial System. Ithaca: Cornell University Press

Sutton, T.G. (1984) Lobbying of Accounting Standard -Setting bodies in the U.K. and the U.S.A: A Downsian Analysis; Accounting, Organizations and Society, vol. 9, No. 1, pp. 23-89

Tricks, H. and Hargreaves, D. (2004) Accounting Watchdog sees trouble; Financial Times, 10 November, pp. 2-18

Zeff, S. A. (2002) Political Lobbying on proposed standards: A challenge to the IASC; Accounting Horizons, March, pp. 9-37

$--0-$ 